\title{
THE USING OF TECHNOLOGY ACCEPTANCE MODEL IN UNDERSTANDING THE APPLICATION PROCESS OF INDONESIAN ACCOUNTING STANDARDS FOR NON-PUBLICLY-ACCOUNTAB LE ENTITIES IN SMES IN PONTIANAK
}

\author{
JUANDA ASTARANI \\ Universitas Tanjungpura
}

MARDIANA KURNIASIH

Universitas Tanjungpura

\begin{abstract}
This study aims to analyze the application of Indonesian Accounting Standards for Non-Publicly-Accountable Entities in SMEs in Pontianak City using Technology Acceptance Model (TAM). This study was conducted in the Pontianak City area using primer data in a form of questionnaire. The total sample in this research was 50 SMEs that were randomly selected. Statistic test used in the data management was Partial Least Square (smartPLS 3.0). The finding of this research shows that the perceived ease of use significantly affects the perceived usefulness and attitude toward using the Indonesian Accounting Standards for Non-Publicly-Accountable Entities, while the perceived usefulness significantly affects the attitude towards using Indonesian Accounting Standards for Non-Publicly-Accountable Entities. Moreover, the attitude toward using the Indonesian Accounting Standards for Non-Publicly-Accountable Entities significantly affects the behavioural intention to use Indonesian Accounting Standards for Non-Publicly-Accountable Entities.
\end{abstract}

Keywords: Technology Acceptance Model (TAM), Indonesian Accounting Standards for Non-Publicly-Accountable Entities, SMEs

\section{INTRODUCTION}

Indonesian Accounting Standards for Non-Publicly-Accountable Entities is an accounting standard published by the Institute of Indonesia Chartered Accountants (IICA) with the objection that the Small and Medium Entities can have a standard financial report suited to their conditions. Indonesian Accounting Standards for NonPublicly-Accountable Entities is the simplicity of the Financial Accounting Standard IFRS based which is the Financial Accounting Standard applied in Indonesia. Because 
of the wide scope of disclosure in the Financial Accounting Standard IFRS based as well as the report demands that are quite unfulfillable, the IICA published an Indonesian Accounting Standards for Non-Publicly-Accountable Entities that is more suited to the condition of small and medium entities.

Accounting in an entity. Accounting itself is a financial report started from the transaction identification stage until the financial report preparation can be utilized in making decision. Accounting itself is considered as a technology because technology is a set of knowled ge that produce beneficial products, and the meaning of the technology is not limited to the physical technology (hard technology), but also soft technology. Technology itself is a facility to solve the existing problems in the real life, as well as a facility to obtain the goal. Therefore, technology itself consisted of cultural contents and values based on where the technology is developed or applied (suwardjono, 2005).

Graffikin in Suwardjono (2005) supported that accounting is a technology, because accounting is designed to facilitate economical activities. Besides, Sudibyo in Suwardjono (2005) also stated that by recognizing the characteristic of accounting, we will understand that a set of accounting knowledge is no more than a technology (soft technology), so its development should suit its nature as technology, to make it more beneficial in affecting certain social environment.

Based on the concept that presumed accounting as a technology, therefore in order to analyze the accounting reception in the form of Financial Accounting Standard, we may use the Technology Acceptance Model. Technology Acceptance Model describes the variables that may affect somebody to use a technology. According to this model, the attitude toward the using of technology is affected by the behavioural intention to use technology and the perceived usefulness. This model also explains that behavioural intention to use the technology is also influenced by the attitude towards the using of technology and the pereceived usefulness.

Attitude towards the using of technology itself is affected by the perceived usefulness and the perceived ease of use. TAM also explains that the perceived of usefulness can be influenced by the perceived ease of use. 


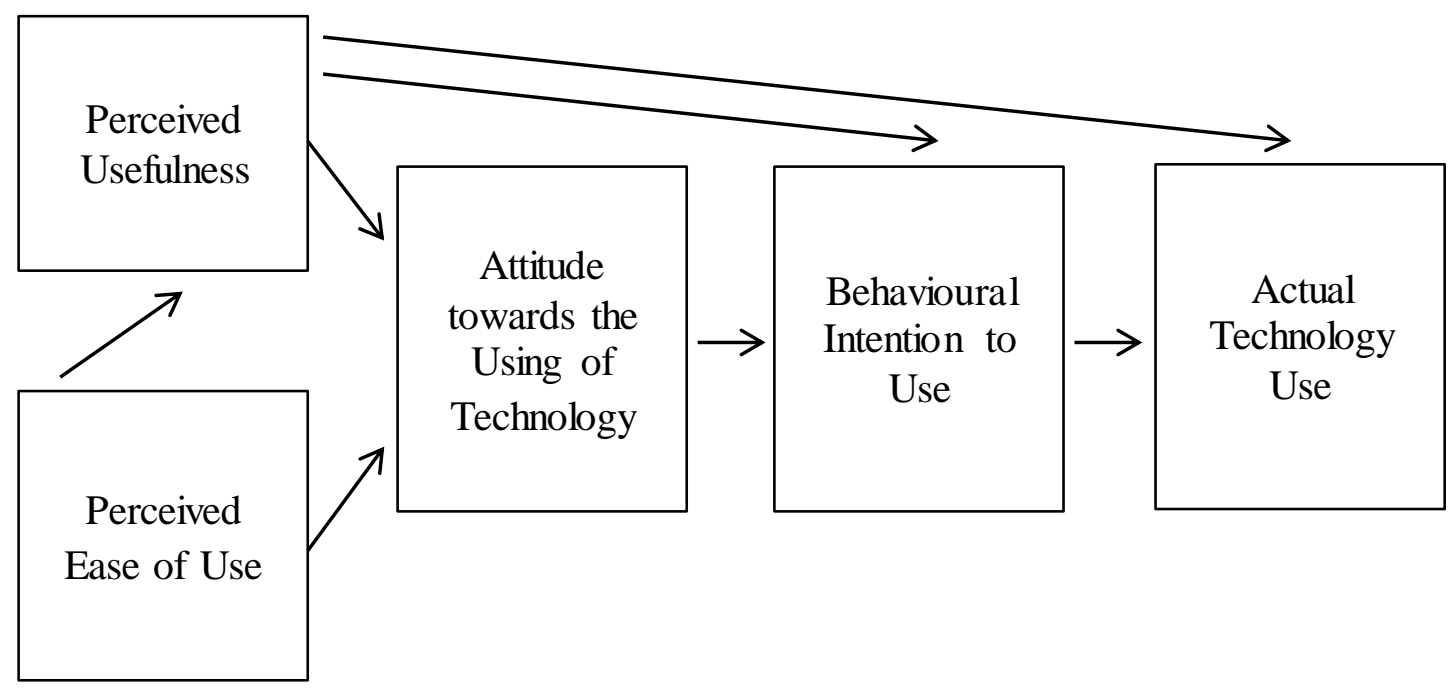

Figure 1.1: Technology Acceptance Model (TAM) that specifically mentions the attitude toward the using of technology.

The new thing is this research is the using of technology acceptance model to analyse the acceptance in the Financial Accounting Standard. By using the notion that Financial Accounting Standard is a part of technology, so the using of Technology Acceptance Model in analyzing the adoption process of Indonesian Accounting Standards for Non-Publicly-Accountable Entities, it is expected to obtain the more comprehensive understanding about the adaption process of a Financial Accounting Standard.

\section{LITERATURE REVIEW}

Indonesian Accounting Standards for Non-Publicly-Accountable Entities Kinerja SAK ETAP stands for Standar Akuntansi Keuangan Untuk Entitas Tanpa Akuntabilitas Publik (in English Indonesian Accounting Standards for Non-PubliclyAccountable Entities). ETAP means the entity that does not have significant public accountability in publishing a financial report for public and external user.

\section{Small to Medium Enterprises}

Small to Medium Enterprises (SMEs) are one of the non-publicly-accountable entities that basically need a financial report to improve their business. To differ between micro, small and medium enterprise, the Law Number 20 Year 2008 is established on July $4^{\text {th }} 2009$ about Micro, Small and Medium Enterprises as follows: 
Table 1. MSMEs Criteria

\begin{tabular}{|c|l|c|c|}
\hline \multirow{2}{*}{ No } & \multirow{2}{*}{ Description } & \multicolumn{2}{|c|}{ Criteria } \\
\cline { 3 - 4 } & & Assets & Revenues \\
\hline 1 & Micro Enterprise & Max IDR 50 million,- & Max IDR300 Million \\
\hline 2 & Small Enterprise & 50 million -500 million & >IDR 300 million $-2,5$ billion \\
\hline 3 & $\begin{array}{l}\text { Medium } \\
\text { Enterprise }\end{array}$ & $\begin{array}{c}\text { >IDR 500 million }-10 \\
\text { billion }\end{array}$ & $>$ IDR 2,5 - 50 billion \\
\hline
\end{tabular}

\section{Technology Acceptance Model (TAM)}

One of the theories related to the using of information and technology system that is presumed to be very influential and generally used to describe the individual acceptance toward the using of information and technology system is Technology Acceptance Model. This theory firstly described by Davis (1986):

\section{Constructs in TAM}

The first Technology Acceptance Model (TAM) that has not been modified using five main contructions. Those five constructs are these followings:

1. Perceived usefulness, which is the perception on the beneficial of the technology used.

2. Perceived ease of use, which is the perception on whether the technology is easy or not when used.

3. Attitude towards behavior or attitude towards using technology, which is someone's attitude related to the using of technology.

4. Behavioral intention or behavioral intention of use, which is the intention in using a technology.

5. Behavior or the actual technology use, which is the actual using of the technology.

\section{RESEARCH METHOD}

\section{Sample}

Samples in this research are the SMEs within the area of Pontianak City with total samples 50 SMEs obtained using random sampling method. 


\section{Data Source and Category}

Data in this research is categorized as subject data. According to Indriantoro and Supomo (1999:145), subject data is research data category consists of behavior, opinion, experience, as well as characteristic of a person or a group of people that became the study subjects /respondents. Based on its source, the data in this research is a primer data.

\section{Research Instrument}

The research instrument used in this study was a questionnaire adopted from Jogiyanto (2007). This questionnaire consists of several adaptations from earlier researchers.

\section{Data Analysis Technique}

The data analysis of this research used the Partial Least Square (PLS) approach to test the hypothesis and the model made on this research. PLS is an alternative approach that shifts from SEM approach co-variant based into variant based.

\section{FINDING AND DISCUSSION}

\section{Construct Validity}

Construct validity shows how well the finding obtained from the use of measurement in accordance with the theories used to define a construct. Construct validity can be assessed using the convergent validity and discriminant validity.

\section{Convergent Validity}

Construct validity from a measurement model with reflective indicator can be measured using loading score, through Average Variance Extracted (AVE) parameter and Convergent Vailidity. Convergent validity valie is the loading factor value on latent variable with its indicators. The expected value is $>0.7$ and AVE $>0.5$.

The finding of this research shows that all the statement items were valid after revision was done to the outer model testing, which was loading factor $>0.5$ and AVE $>$ 0.5. It shows that each has AVE score beyond 0.5. Accordingly, it can be inferred that the construct has a good convergent validity shown on the appendix. 


\section{Discriminant Validity}

Discriminant Validity on reflective indicator of outer model is assessed based on the cross loading factor value with the useful construct to find out whether the construct has adequate discriminant. The loading value on the intended construct must be greater than the latent construct value. If the correlation of the construct with the measurement item is greater than the other construct size, it shows that the latent construct predicts their block size better than the other block size.

In the appendix, it can be seen that the discriminant validity in the table above are considered as good because the correlation value of the indicator with the other construct, loading factor PU6 with Perceived Usefulness/PU was 0.858. This number is higher than the loading factor PU6 with other constructs, which are Perceived Ease of Use (PEOU), Behavioural Intention Use (BIU) and Attitude toward Using (ATU) which are 0.369, 0.532 , and 0.489 consecutively. Therefore, we can draw a conclusion that construct predicts indicator on their block better than the indicator on the other blocks.

\section{Construct Reliability}

Construct Reability on the reflective indicator measurement model can be measured by assessing the composite reliability value from the indicator block that measures the construct. A construct is realible if it has composite reliability >0,70 (Jogiyanto, 2009:62).

The appendix of this research shows that all the constructs $n$ the model that are estimated has fulfilled reliable criteria because each construct has composite realibility value > 0.7. The Perceived Usefulness (PU) has the highest composite reliability of 0.911 while Behavioural Intention of Use (BIU) has the lowest composite reliability of 0.872.. The Cronbach's Alpha values for all constructs are higher than 0.7, even though they have 0.6 value at the exploration study. Behavioural Intention of Use (BIU) has the lowest value of 0.782 , while the Perceived Usefulness (PU) has the highest value of 0.868 so it can be stated that the measurement in this research is reliable.

\section{Structural Model or Inner Model Evaluation}

The structural model or inner model testing was done to see the relationship among the construct, significance value, and R-square from the research model. Structural model was evaluated using R-square for t-test dependent construct as well as the significance of 
the structural line of coefficient parameter (Yusman: 2013). In assessing the structural model using PLS, it started with viewing the R-square for each variable.

Table 4.10 that can be seen on the appendix shows that the R-square value for Perceived Usefulness (PU) variable is 0.123 . This indicates $12.3 \%$ perceived usefulness (PU) variable can be affected by the perceived ease of use (PEOU) and behavioural intention of use (BIU), while the rest $87.7 \%$ is affected by the other variables outside those observed.

The R-square value for attitude toward using (ATU) variable is 0.408. This means that $40.8 \%$ attitude toward using (ATU) variable can be affected by the perceived ease of use (PEOU), perceived usefulness (PU) and behavioural intention of using (BIU), while $59,2 \%$ the rest are affected by other variable outside those observed.

The R-square value for behavioural intention of using (BIU) variable is 0.272 . This means that $27.2 \%$ behavioural intention of using (BIU) variable can be affected by the perceived ease of use (PEOU), perceived usefulness (PU), while the rest 79,2\% behavioral intention of using (BIU) are affected by other variable outside those observed.

\section{Discussion}

\section{The Effect of Perceived Ease of Use (PEOU) with Perceived Usefulness (PU)}

The relationship between the perceived ease of use/PEOU with perceived usefulnes s/PU is significant with $\mathrm{T}$-statistic is above 1.96, which is 3.425 . Original sample estimate value is positive which is 0.35 ; shows the relationship between perceived ease of use/PEOU with perceived usefulness/PU is positive. The significant finding of the test on hypothesis 1 proved that the perceived ease of use positively affects the perceived usefulness. This finding confirms that the easier Indonesian Accounting Standards for Non-Publicly-Accountable Entities when applied, the more beneficial the using of the Indonesian Accounting Standards for Non-Publicly-Accountable Entities. The ease of the using of Indonesian Accounting Standards for Non-Publicly-Accountable Entities will improve the benefits of Indonesian Accounting Standards for Non-PubliclyAccountable Entities in SMEs' financial reports. The study that supports this research was done by Davis (1989) and Yusman (2013) which stated that the perceived ease of use (PEOU) positively affects the perceived usefulness (PU). 


\section{The Effect of Perceived Usefulness (PU) to Attitude towards Using (ATU)}

The relationship between the perceived ease of use/PEOU with attitude toward using/ATU is significant with T-statistic is above 1.96, which is 3.954. Original sample estimate value is positive, which is 0.416 . The finding of the test on hypothesis $\mathrm{H} 2$ is positive and significant proved that the perceived usefulness positively affects the attitude towards using. This finding confirms that the more benefits they get, the users will be more satisfied which finding in the increasing of positive attitude from the users who implement the Indonesian Accounting Standards for Non-Publicly-Accountable Entities.

The Effect of Perceived Ease of Use (PEOU) to the Attitude Toward Using (ATU)

The relationship between the perceived ease of use/PEOU with attitude toward using/ATU is significant with T-statistic is above 1.96, which is 3.434 . Original sample estimate value is positive which is 0.361 which shows that the relationship between perceived ease of use/PEOU with attitude towards using/ATU is positive. The finding of the test on hypothesis $\mathrm{H} 3$ is positive and significant, proved that the perceived ease of use positively affects the attitude towards using. This finding confirms that the easier Indonesian Accounting Standards for Non-Publicly-Accountable Entities when applied, the better attitude of the Indonesian Accounting Standards for Non-Publicly-Accountable Entities users and it results in positive attitude in a form of enjoying its application.

The Effect of Attitude towards Using (ATU) to the Behavioural Intention of

\section{Using (BIU)}

The relationship between the attitude toward using/ATU with the behavioural intention of using (BIU) is significant with T-statistic is above 1.96, which is 5.856 . Original sample estimate value is positive which is 0.522 which shows that the relationship between the attitude toward using/ATU with the behavioural intention of using (BIU) is positive. This finding confirms that the better attitude of Indonesian Accounting Standards for Non-Publicly-Accountable Entities users, the more enjoy the users on using Indonesian Accounting Standards for Non-Publicly-Accountable Entities, that leads to the increase of behavioural intention of using the Indonesian Accounting Standards for Non-Publicly-Accountable Entities. 


\section{SUMMARY}

This research aims to analyze the application of Indonesian Accounting Standards for Non-Publicly-Accountable Entities using Technology Acceptance Model in the SMEs in Pontianak City. Variables or constructs used in this research are perceived ease of use, perceived usefulness, attitude towards using, behavioural intention to use. This research use partial least square to analyze the relationship between variables. Based on the analysis and discussions in earlier parts, we can conclude as follows:

1. The finding of this research shows that the perceived ease of use (PEOU) positively affects the perceived usefulness (PU). This means that the ease on the use of Indonesian Accounting Standards for Non-Publicly-Accountable Entities will affect the user in implementing the Indonesian Accounting Standards for Non-Publicly-Accountable Entities because it is presumed will improve their work performance.

2. The finding of this research shows that the perceived usefulness (PU) positively affects the attitude towards using (ATU) of Indonesian Accounting Standards for Non-Publicly-Accountable Entities. This means that the more benefits the users get will improve the attitude of the users in implementing Indonesian Accounting Standards for Non-Publicly-Accountable Entities in financial reports.

3. The finding of this research shows that the perceived usefulness (PU) positively affects the attitude towards using (ATU) of Indonesian Accounting Standards for Non-Publicly-Accountable Entities. This means that the more benefits the users get will improve the attitude of the users in implementing Indonesian Accounting Standards for Non-Publicly-Accountable Entities in financial reports.

4. The finding of this research shows that the perceived ease of use (PEOU) positively affects the attitude towards using (ATU). This means that the ease in using the Indonesian Accounting Standards for Non-Publicly-Accountable Entities felt by the users will finding in a positive attitude because implementing 
Indonesian Accounting Standards for Non-Publicly-Accountable Entities will bring enjoyment in its interactions.

5. The finding of this research shows that the attitude toward using (ATU) the Indonesian Accounting Standards for Non-Publicly-Accountable Entities positively affects the behavioural intention to use (BIU) Indonesian Accounting Standards for Non-Publicly-Accountable Entities. This proves that the better attitude of the users in implementing Indonesian Accounting Standards for NonPublicly-Accountable Entities, the more enjoy the users in implementing Indonesian Accounting Standards for Non-Publicly-Accountable Entities , which results in the improvement on the behavioural intention to use Indonesian Accounting Standards for Non-Publicly-Accountable Entities.

\section{Research Limitations}

Some limitations in this research are:

1. This research has total 50 defined samples, because of restricted research time and the unwillingness of the respondents to fill the questionnaire.

2. The scope of this research only reached Pontianak City; in consequence, it does not represent much the perception or the understanding level of the acceptance of information system in other areas.

3. The limitation in survey method, which the observer cannot control the veracity of the respondents' answers in answering the questions.

\section{Implication and Recommendation}

Based on the conclusion and limitation of the research that had been mentioned aforehand, these followings are the implication and recommendation given:

1. The next researcher should widen the sampling area to represent wider population.

2. The next researcher should add more samples and develop the survey method, such as using interview to obtain more integrated information. 


\section{REFERENCES}

Astarani, Juanda (2008). Faktor-Faktor Yang Mempengaruhi Niat Akuntan Menggunakan Software Bajakan (Tesis yang tidak dipublikasikan), Universitas Gadjah Mada, Indonesia.

Bhilawa, L. (2010). Analisis Penerimaan Mobile Banking (M-Banking) dengan Pengalaman (Experience) Sebagai Variabel Eksternal dengan Menggunakan Pendekatan Technology Acceptance Model (TAM). Fakultas Ekonomi. Universitas Sebelas Maret, Surakarta.

Davis, F.D., (1989). Perceived usefulness, perceived ease of use, and user acceptance of information technology.MS Quarterly (online), Vol. 13 ISS.3, pg. 318.

Fitakhurrokhmah.(2013). Pengaruh Persepsi Kemudahan Penggunaan Dan Persepsi Kegunaan Terhadap Penggunaan Standar Akuntansi EntitasTanpa Akuntabilitas Publik Pada Bank Perkreditan Rakyat(BPR) Di Malang Raya. Diperoleh dari http://jimfeb.ub.ac.id/index.php/jimfeb/article/view/251 Diakses 1 Agustus 2016

Ghozali, Imam (2008). Structural Equation Modelling. Metode Alternatif Partial Least Square. Badan Penerbit Undip, Semarang.

Jogianto (2007).Sistem Informasi Keperilakuan, Penerbit Andi, Yogyakarta.

Sugiyono (2003).Metode Penelitian Bisnis, Pusat Bahasa Depdiknas, Bandung.

Tangke, Natalia (2004). Analisa Penerimaan Penerapan Teknik Audit Berbantuan Komputer (Tabk) Dengan Menggunakan Technology Acceptance Model (Tam) Pada Badan Pemeriksa Keuangan (BPK) RI. Diperoleh dari http:/jurnalakuntansi.petra.ac.id/index.php/aku/article/view/16151

Wibowo, Arief (2006). Kajian Tentang Perilaku Pengguna Sistem Informasi dengan Pendekatan Technology Acceptance Model (TAM). Diperoleh dari http://peneliti.budiluhur.ac.id/wpcontent/uploads/2008/.../arif+wibowo.pdf,

Yusman (2013).Analisis Sistem Informasi Keuangan Daerah Dengan Menggunakan Technology Acceptance Model Pada Pemerintah Daerah Kabupaten Sinjai. Skripsi Jurusan Akuntansi, Fakultas Ekonomi dan Bisnis, Universitas Hasanuddin. 
